\title{
Research on the Influencing Factors of Patent Commercialization in Chinese Enterprises under the Background of Association of Southeast Asian Nations
}

\author{
Ming-zhu Ding \\ Guangxi University of Science and Technology \\ Liuzhou, China \\ 1467925168@qq.com
}

\author{
Zhao-hui Chen \\ School of Management \\ Guangxi University of Science and Technology \\ Liu Zhou, P. R. China \\ chance168@163.com
}

\begin{abstract}
With the implementation of the national "One Belt And One Road" strategy, ASEAN has become an essential partner for Chinese enterprises to "go global". The purpose of this paper is to help Chinese enterprises to develop appropriate patent commercialization strategies. On the basis of combing relevant documents, this paper adopts the research method of induction and summary. In the context of ASEAN, Chinese enterprises' patent commercialization strategy is mainly influenced by policy factors, market, technology, service and other factors. This paper argues that companies should strengthen cross-border cooperation in patent protection in order to seek policy support from ASEAN; secondly, in order to strengthen patent warning work, enterprises should improve the intermediary service system; third, companies should improve their independent innovation capabilities and form their own technological competitive advantages; on the whole, Chinese companies should strengthen strategic cooperation with ASEAN to achieve mutual benefit and win-win results.
\end{abstract}

Keywords-Association of southeast Asian nations (ASEAN); Patent Commercialization; Influence factor; Patent strategy

\section{INTRODUCTION}

Since the implementation of China's patent law and intellectual property strategy, the number of patent applications in China has sharply increased, the patent structure has been constantly optimized, and the patent competitiveness has been gradually enhanced. Judging from the number of patent applications and signed technical contracts, China has become a large country of patents, but the quality of patents in China has always existed. The creativity of domestic patents are far less than those of foreign countries. The poor quality of patents is partly due to policy guidance, which fails to reflect the premise of commercialization. The status quo of patent commercialization cannot be ignored. The conversion rate of scientific and technological achievements in China is only about $10 \%$, far lower than $40 \%$ in developed countries.

Enterprises are the mainstay of the market and the mainstay

D.C. thanks two fund projects: the National Natural Science Foundation of China (Grant No. 71864005), Guangxi University of Science and Technology Postgraduate Research Innovation Project (Grant No.GKYC201716). of technological innovation. The implementation of "One Belt And One Road" strategy has brought a broad market for Chinese enterprises. More and more Chinese companies will seize the opportunity to find ASEAN trading partners. Although China and ASEAN fully launched the free trade area in 2010, Chinese enterprises still need to make full use of their patent advantages and formulate reasonable patent commercialization strategies to enhance their competitive advantages in the ASEAN market. Only in this way can we cope with the ten ASEAN countries with huge economic differences and diverse legal systems. Current studies show that China and ASEAN countries are still complementary in trade, so it is wise to take the "One Belt And One Road" as an opportunity to expand bilateral economic cooperation [1].

\section{CONNOTATION OF PATENT COMMERCIALIZATION}

China's patent law originally issued in 1984 stipulates that the patent right refers to the patent right enjoyed by the patentee. Patent rights have the nature of monopoly. A patent right is an exclusive right, and the patente or the successor of the right is protected by law within a certain period of time. The term "patent exploitation" is the predecessor of "patent commercialization", which means that the patente or the patente authorizes others to manufacture, use and sell the patented product or use the patented method for the purpose of production and operation. In theoretical research, many scholars use the term "patent implementation". They believe that the original meaning of "patent implementation" is to realize its commercialization and industrialization [2]. The meanings of the words "patent transfer" and "achievement transformation" are similar to the meanings of "patent commercialization".

At present, there are still differences in the definition of patent commercialization given by different scholars at home and abroad. Shane considers that the patent commercialization method includes the following aspects: selling a patent, transferring a patent to a company, and establishing a new company or producing a new product through the transfer of the patent [3]. Svensson argues that commercialization is not about thinking about whether patents are profitable, or whether 
non-commercial patents might also be beneficial to owners. He believes that the key to patent commercialization is whether innovation is introduced in the market and whether entrepreneurs participate in some form of entrepreneurial activities that have been ignored in previous literature [4]. Broughner jem and Swenson consider patent commercialization in terms of patent sales and licensing. Chen Zhaohui believes that patent commercialization is a process of creating and realizing the value of patents. How to create or utilize patent value is the core issue of enterprise patent commercialization [5]. Wu Jianzu believes that patent commercialization requires the patent to be regarded as an option. The process of commercialization is to choose the right time to make the company get the investment opportunity or the highest profit [6]. Cao Yong believes that the process of patent commercialization mainly includes alternative patents into products within the validity period and recovering research and development costs and obtaining benefits through licensing and transforming [7]. Technological innovation is a kind of economic activity, which usually needs to go through the stages of invention, creation, technology transformation, commercial production and product sales [8]. Patent commercialization is inseparable from new ventures or products. Therefore, this paper believes that patent commercialization is a business activity of a company that generates performance or increases market share through patents.

\section{ANALYSIS OF THE INFLUENCING FACTORS OF PATENT COMMERCIALIZATION}

Through the literature review of domestic and foreign scholars on the factors affecting the commercialization of patents, it is found that the process of patent commercialization is influenced by many factors. Chih-Hung Hsieh believes that external cooperation, business plans and risk sharing programs all have a significant impact on patent commercialization. Hamad B. Olayan believes that the factors affecting the commercialization of technology mainly include technology, law, economic development, competitive technology and market. Brian t. Schcales believes that the three aspects that affect the performance of technology commercialization include technology state, resource state and risk state. $\mathrm{Wu}$ Jianzu and Chen Xueli believe that the entry speed of competitors and the impact of competitors on the market will affect the process of patent commercialization. Li Liangcheng believes that technical, market; service and institutional factors will have a significant impact on the commercialization of patents. Chen Zhaohui proposed that high-quality patents, teams, complementary assets and business models will affect the entrepreneurial problems of patent commercialization; through the model analysis, Zhang Yongcheng finds that the main factors affecting the commercialization of patents are innovation consciousness, internal evaluation system, intermediary service system and government thrust. Zeng $\mathrm{Li}$ and Luo Xiaohan believe that patent commercialization attaches great importance to the materialized results of patent technology. Through literature review, this paper analyzes the background of AESAN from the perspective of environment. This paper argues that the influencing factors of patent commercialization are not only in the process of patent transformation and implementation, but also in the work of patent protection in the early stage of patent commercialization. Through empirical research, Cao Yong and Zhao Li concluded that there was a significant positive effect between patent protection and patent commercialization. Zhang Yuqing also agrees that the enhancement of protection is conducive to the commercialization of patents.

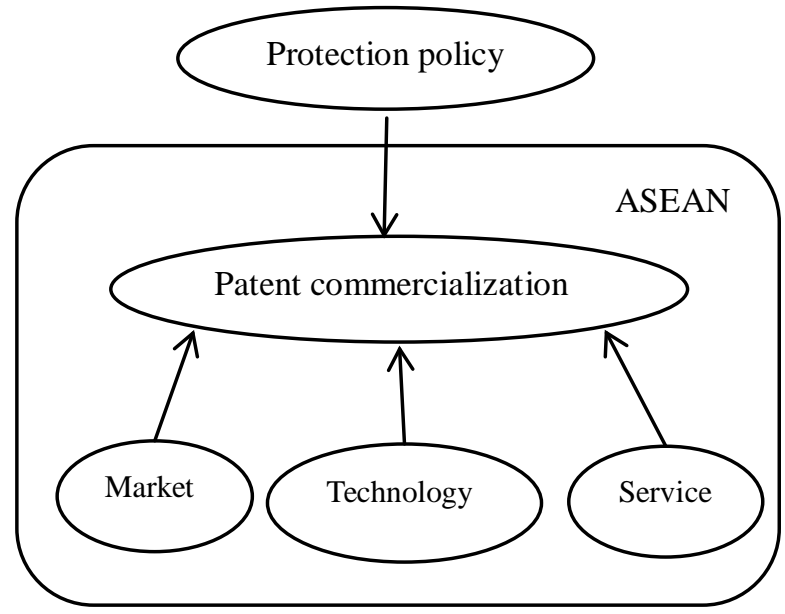

Fig. 1. Factors of patent commercialization

\section{A. Disadvantages of patent protection}

Although the number of patent applications in ASEAN has increased in recent years, the total number of domestic applications in patent applications is still at a low level. Singapore is economically developed among ASEAN countries, but foreign patent applications in Singapore still account for $95 \%$. A large part of the patents come from established countries such as the United States, Japan and Germany. In this situation, it is difficult for China to make a patent layout in ASEAN area. After years of layout, the United States, Japan and other countries have already formed patent barriers. The competitive advantage of Chinese enterprises in ASEAN market has disappeared. Chinese companies need to be careful in the complex process of making and selling products, which can inadvertently touch a foreign patent minefield. In the ASEAN market, the first-mover advantage of developed countries has greatly inhibited the development of Chinese enterprises.

\section{B. Obstructing factors of patent intermediary service system}

In July 2017, General Secretary Xi Jinping made important instructions during the 16th meeting of the Central Financial and Economic Leading Group. He clearly pointed out that strengthening intellectual property protection is closely related to creating a good business environment and accelerating the construction of an open economic new system. Creating a good business environment requires IP service agencies to serve enterprises. In the face of the complex patent commercialization environment in ASEAN countries, Chinese enterprises not only need to make adequate preparations themselves, but also need to timely obtain necessary information, such as the latest patent policies, the talent markets and other supporting services of intellectual property. 
However, there are very few intellectual property service agencies in China that can provide information services for enterprises in the ASEAN market. As far as the current situation is concerned, the lack of domestic and foreign intellectual property service systems is a hindrance to the commercialization of patents in Chinese enterprises.

\section{Barriers to patent quality}

Technical competence is the foundation of business innovation. In order to successfully carry out commercialization of patents, it is necessary to excavate the value of patented technology. Generally speaking, the novelty, complexity and importance of patented technology all affect the possibility of commercialization of patents. In fact, the successful commercialization of innovative products often depends on the technological creativity of enterprises. The novelty of technology is conducive to tapping and even creating the user demand for products. The complexity of technology may be reflected in the product quality and technological content, which helps to endow the product with market value. Patent technology is a resource of enterprises. High-quality patent is regarded as a magic weapon of commercialization, which can stand the test of the market and has promising prospects.

\section{The complexity of the ASEAN market}

Due to the complex market in ASEAN area, patent commercialization may be impacted. That would increase the risk of commercialization. The patent itself is a possession of legal rights and has the nature of monopoly. Patents need to be commercialized in the market, so some enterprises achieve their monopoly position through strategic patents. The strategic patents adopted by enterprises are in order to realize monopoly interests. Enterprises use the legal protection mechanism to apply for alternative patents or patents portfolios. Enterprises can form a technological monopoly to occupy the market. Strategic patents require more $R \& D$ investment from the company. The ten ASEAN countries have different languages, different cultures and different religious beliefs. Due to intermittent policies, the ASEAN market is full of "crisis".

\section{COUNTERMEASURES AND SUGGESTIONS TO PROMOTE THE COMMERCIALIZATION OF ENTERPRISE PATENTS}

\section{A. Seeking patent protection for transnational cooperation}

ASEAN countries lack the capacity of independent innovation. Foreign applications account for $90 \%$ of the total number of domestic patent applications. The patent barriers established by developed countries have severely restricted the development of the native countries. Similarly, Chinese companies are eager to gain a foothold in the ASEAN market due to their geographical advantages. Under such circumstances, Chinese enterprises should actively express their willingness to cooperate with local enterprises and governments, as soon as possible enhance the influence and dominant position of patents in China's "One Belt And One Road" strategy. At the same time, we require developing cross-border friendly cooperation and form a patent strategic alliance between China and ASEAN. It is a must for us to continue to raise the awareness of patent protection within Chinese enterprises and strengthen the creativity, applicability, protection, management and service of patent rights. We should fully understand the patent system and legal system of the host country and competitors. Grasp the key points in the process of patent commercialization, not only focus on patent applications, but also apply and protect.

\section{B. Improve the intermediary service system and build an early warning mechanism}

Most of China's enterprises entering the ASEAN market are private enterprises. They don't have enough funds and departments to support the company's patent management. As a result, enterprises may not fully understand the patent policies and patent systems of ASEAN countries. At the same time, it may also lead to an erroneous strategy in the company's patent commercialization process, so that the company's interests are not fully protected. There are many functions of patent intermediary service agencies, including applying for patent protection as an agent, guiding the adjustment of the company's patent strategy, forming linkage with the local government, and providing opinions and Suggestions for the selection of upstream and downstream partners of the company.

\section{Improve independent innovation ability and develop technologies in key areas}

In the ASEAN market, there is a tremendous gap in the development of China's technology in key areas compared with developed countries. Chinese companies recognize the ability to innovate independently, especially with the core competitiveness of enterprises. In the context of open innovation, most private companies may not be able to afford high costs to invest in $\mathrm{R} \& \mathrm{D}$ resources internally. In this case, the innovation ability of enterprises can be improved through the technology introduction, strategic alliance and industry-university-research cooperation. Only by developing core products with independent intellectual property rights, can Chinese enterprises truly be invincible in the ASEAN market.

\section{Strengthen strategic cooperation and establish cooperative partnership with ASEAN countries}

Facing the complex ASEAN market, Chinese enterprises should adopt a cooperative attitude in order to occupy a place in the ASEAN market. Here is a realistic example. On March 8 , 2018, Shopee, an e-commerce platform in Southeast Asia and Taiwan, announced a strategic partnership with honor. This cooperation has enabled Shopee Mall to successfully sell the glory 9 Youth Edition in Malaysia. The Shopee and Glory Honor have become strategic partners, providing more choices for Shopee consumers.

\section{CONCLUSION}

With the implementation of globalization strategy, trade barriers, tariff barriers and even administrative barriers among countries are being continuously eliminated. At this time, the protection of patents becomes more and more crucial. In the context of "One Belt And One Road" strategy, the cooperation between China and ASEAN countries becomes more and more frequent. It is urgent to promote the commercialization of patents in China. Chinese companies should seize opportunities and respect cultural differences after entering the ASEAN market. At the same time, Chinese companies have to find the optimal path for patent commercialization, and improve patent 
protection awareness and independent innovation capability. We hope that enterprises can explore a new world in the ASEAN market with the lowest cost, the fastest method and flexible patent strategy. Obviously, there will be a variety of new problems in the process of business commercialization waiting for follow-up research.

\section{REFERENCES}

[1] Xing Li, Jin bo Wang, Jiying Tong, Measurement and analysis of china-ASEAN trade structure. Hebei, vol. 9, pp. 18-5, 2018. (In Chinese)

[2] Liying Wang, Jin Chen, Analysis on the status quo of enterprise patent implementation and its influencing factors -- based on the empirical study in Zhejiang province, vol. 30. pp. 148-153,1892.(In Chinese)
[3] S. Shane, Technological opportunities and new firms creation, vol. 47, Management Science, pp. 205-220, 1963.

[4] R. Svensson., Commercialization of patents and external financing during the R\&D phase, Sweden, vol. 36, pp. 1052-1069, September 2007.

[5] Zhouhui Chen, Xuezhong Zhu, Power generation and strategy selection of patent commercialization: an explanation based on patent motivation, vol. 30, pp. 1-6, 2011.(In Chinese)

[6] Jianzu Wu, Xueli Chen Research on the commercialization timing of enterprise patents under competitive conditions, vol. 10, pp. 51-54, 2010.(In Chinese)

[7] Yong Cao, Li Zhao, Yang Zhang, Chujun Luo, Empirical study on the correlation between patent management and technological innovation performance of high-tech enterprises, vol. 10, pp. 182-183,2010.(In Chinese)

[8] Min Luo, Research on incentive mechanism of commercialization of low-carbon patents, vol. 10, pp. 1795-1800+1913,2018.(In Chinese) 